\title{
Pre-charge identification of a minor and Article 14 of the ECHR: Judgment In the Matter of an Application by JKL (A Minor)
}

FAITH GORDON

\author{
The Australian National University, Canberra, Australia
}

\section{Introduction}

It is possible very effectually to poison the fountain of justice before it begins to flow. It is not possible to do so when the stream has ceased. ${ }^{1}$

$\mathrm{P}$ re-charge identification of those accused of involvement in crime raises considerable concerns in relation to balancing the interests of all parties, while maintaining one of the core foundations underpinning the criminal justice system - the presumption of being 'innocent until proven guilty'. ${ }^{2}$ The issue of pre-charge identification has been the subject of debate in recent years following the publication of the identity of a number of celebrities who were arrested in relation to allegations of historic sexual abuse and were subsequently released without charge. ${ }^{3}$ Their arrests attracted intense media coverage, nationally and internationally. ${ }^{4}$ A landmark decision following an action by Sir Cliff Richard against the $\mathrm{BBC}$ brought public and media attention directly to the consequences of precharge identification. ${ }^{5}$

There have been several calls for policy reform to this area of the law. In Northern Ireland, the negative consequences of pre-charge identification have been referred to by the Gillen Review, which explored the law and procedures in the context of serious sexual offences. The final report released in 2019 clearly recommended that: ' $\mathrm{t}$ ] he identity of the accused should be anonymised pre-charge'. ${ }^{6}$ However, previous attempts in the UK

$1 \quad R v$ Parke [1903] 2 KB 432, cited in C Burgess, 'Can “Dr Death” receive a fair trial?' (2012) 7(1) Queensland University of Technology Law Journal 16-28.

2 Woolmington v DPP [1935] AC 462, 481; Article 14 International Covenant on Civil and Political Rights. See also F Gordon, 'Guilty until proven innocent? How a legal loophole is being used to name and shame children’ The Conversation (6 November 2017) < https://theconversation.com/guilty-until-proven-innocenthow-a-legal-loophole-is-being-used-to-name-and-shame-children-86073>.

3 Examples include: Paul Gambaccini, Matthew Kelly, Sir Cliff Richard and Jimmy Tarbuck.

4 For example: 'BBC radio presenter Paul Gambaccini arrested in sex abuse inquiry' ABC News Australia (2 November 2013); 'Cliff Richard's Berkshire property "searched by police in relation to alleged historical sex offence"” Huffington Post (14 August 2014).

5 Sir Cliff Richard OBE v BBC [2018] EWHC 1837 (Ch), Case No HC-2016-002849, 18 July 2018.

6 The Gillen Review <www.justice-ni.gov.uk/sites/default/files/publications/justice/gillen-report-may2019.pdf>: Recommendation 10, page 30. 
such as the unsuccessful Anonymity (Arrested Persons) Bill, introduced in 2011 by the Conservative MP and barrister, Anna Soubry, did not progress beyond second reading. On 21 January 2020 a version of the Anonymity (Arrested Persons) Bill [HL] 2019-21, went through a first reading in the House of Lords and, at the time of writing, a date for the second reading has not been scheduled. ${ }^{7}$

These existing discussions and unsuccessful policy interventions in the area of precharge identification have predominantly been centred on the experiences of adults who have been identified pre-charge and, notably, the same attention has not been given to the negative implications for minors who have also been identified pre-charge. ${ }^{8}$ This altered in October 2015 with the arrest and police interview of a 15-year-old boy with Asperger's syndrome for an alleged cybercrime involving the 'hacking' of the databases of the TalkTalk telecoms company. The boy had his identity published, with details such as his name, age, place of residence and photograph, featuring in various media outlets including newspapers, such as the Daily Mail, Daily Telegraph and The Sun, as well as circulation via online media on Twitter and Google. ${ }^{9}$

\section{Pre-charge identification of a minor}

The case of JKL commenced in 2015, with proceedings in the High Court in Northern Ireland calling for the removal of the child's details and injunctions sought against future publications by organisations such as Google and Twitter. ${ }^{10}$ In judicial review proceedings in 2016, counsel representing the child shone a light directly onto the lacuna in the current legislative framework. ${ }^{11}$ Counsel for the applicant argued that the government's decision to implement legislation under Article 22 of the Criminal Justice (Children) (Northern Ireland) Order 1998, to cover reporting restrictions for children post-charge and at court, but not at the pre-charge stage for minors who are not charged with any criminal offence, was contrary to common law rules of fairness. It was also argued that failure by the Department of Justice in Northern Ireland to enact section 44 of the Youth Justice and Criminal Evidence Act 1999, introduced as part of New Labour's aim of modernising the youth justice system, was contrary to Article 8 of the European Convention on Human Rights (ECHR) and contrary to section 6 of the Human Rights Act 1998 (HRA).

Judge Colton, sitting in the Northern Ireland High Court, dismissed an application for judicial review in December 2016. In his judgment, Colton J acknowledged that, while the issue was one of social significance, he was of the view that the Department of Justice could not be compelled to legislate on this matter. ${ }^{12} \mathrm{He}$ asserted that the case made by the applicant relating to positive duties imposed on the state by Article 8 of the ECHR

7 For further details see Bill Stages - Anonymity (Arrested Persons) Bill [HL] 2019-21 <https://services.parliament.uk/Bills/2019-21/anonymityarrestedpersonsbill/stages.html>.

8 F Gordon, 'Pre-charge identification of minors: responses, rights and reform' (2020, forthcoming) Criminal Law Review.

9 'TalkTalk hack boy 15 arrested in Northern Ireland over attack' The Independent (London 26 October 2015) <http://www.independent.co.uk/news/uk/home-news/talktalk-hack-boy-15-arrested-in-northern-irelandover-attack-a6709831.html>.

10 The applicant issued civil proceedings against Telegraph Media Group Ltd, Associated Newspapers Ltd, News Group Newspapers Ltd, Google Inc and Twitter International Company.

11 Judgment in the Matter of an Application by JKL (A Minor) to Apply for Judicial Review and in the Matter of a Decision of the Department of Justice: initial judgment delivered 21 December 2016 Ref COL10137 [2016] NIQB 99, and second judgment delivered 26 March 2020 Ref: COL11232 [2020] NIQB 29.

12 Initial judgment (n 11) paragraph 63. 
was 'unsustainable',13 and that a human rights challenge may not be brought on the grounds of a failure to legislate. ${ }^{14}$

\section{Consideration of Article 14 of the ECHR}

An appeal to the UK Court of Appeal saw the case remitted back to the High Court in Northern Ireland in 2019, for a first instance decision on a new argument raised by counsel for the applicant. The new argument centred on whether Article 14 of the ECHR had been breached. ${ }^{15}$ In considering the question of discrimination, Colton J referred to $R$ (Stott) $v$ Secretary of State for Justice ${ }^{16}$ and $R$ (DA \& Others) $v$ Secretary of State for Work and Pensions, ${ }^{17}$ and he directly applied Lady Black's four-stage approach in Stott. The four-stage test for Article 14 to be engaged comprises: the alleged discrimination must fall within the ambit of a Convention right; the different treatment must have been on the grounds of one of the characteristics listed in Article 14 or the applicant's 'other status'; the claimant and person who is treated differently must be in analogous situations; and there must be no objective justification for the different treatment. ${ }^{18}$

There was no dispute between the parties that the applicant's situation engaged his Convention rights under Article 6 and 8 of the ECHR. ${ }^{19}$ The court considered whether the differential treatment complained of could be said to derive from the applicant's 'other status' under Article 14. Colton J considered the case law on the definition of 'other status', noting the difficulty in defining the concept as the 'jurisprudence as to what are the precise boundaries of "other status" is not clear'. ${ }^{20}$ The decision in Stot 21 can be traced back to cases such as Clift $v U K{ }^{22}$ When the European Court of Human Rights considered the matter, it reviewed its decisions in which Article 14 was considered. ${ }^{23}$ The analysis determined that the words 'other status' have been given a wide meaning 24 and that the court "should take a "relatively broad view" of what constitutes "other status" in Article 14'.25

In the case of $J K L$, Colton $J$ stated that ' $[w]$ hether or not the applicant enjoys "other status" for the purpose of Article $14 \ldots$ is by no means straight forward' and that:

13 Ibid paragraph 28.

14 Section 6 of the HRA was drawn upon in this aspect of the case: ibid paragraphs 28-29.

15 Second judgment (n 11).

16 [2018] 3 WLR 1831.

17 [2019] UKSC 21.

$18 R$ (Stott) $v$ Secretary of State for Justice [2018] 3 WLR 1831, paragraph 8.

19 European Convention on Human Rights < https://www.echr.coe.int/Documents/Convention_ENG.pdf > . Article 6 of the ECHR outlines that: 'the press and public may be excluded from all or part of the trial in the interest of morals, public order or national security in a democratic society, where the interests of juveniles or the protection of the private life of the parties so require, or to the extent strictly necessary in the opinion of the court in special circumstances where publicity would prejudice the interests of justice'. Also, Article 8 provides for the right to respect for a person's 'private and family life $\ldots$ home $\ldots$ and correspondence'.

20 Second Judgment (n 11) paragraphs 25-27.

21 Stott (n 18).

22 [2010] ECHR 7205/07.

23 Second judgment (n 11) paragraph 31.

24 Ibid.

25 Ibid paragraph 41. 
the fact that he is a minor is innate or personal to him but his status for the purposes of this application depends on something extra, namely the fact that he has been arrested and interviewed in relation to a criminal offence. ${ }^{26}$

Colton J concluded that, in light of the 'liberal and broad interpretation' that has been adopted, the cause of the discrimination did fall within the remit of Article $14 .{ }^{27}$ Colton J stated that counsel for the applicant had 'not really focused on whether the applicant is in an analogous situation to someone who appears before a court charged with a criminal offence but has rather focused on ... what might be described as the pre-charge and postcharge dichotomy', namely whether there is 'lack of any objective justification for their different treatment'. ${ }^{28}$ Counsel for the applicant proposed that any difference could not be justified. In response to this, counsel for the respondent put forward an argument that 'there is no reasonable expectation of privacy during proceedings in open court, as courts operate openly and subject to the full scrutiny of the public'. ${ }^{29}$ However, ' $[t]$ he requirements of public justice are such that it is necessary to have statutory intervention to protect the interests of minors, particularly their Article 8 interests' ${ }^{30}$ Further, it was argued that there is no involvement of the court at the investigatory stage of the criminal process, and 'depending on the circumstances, a minor is likely to have a reasonable expectation of privacy at common law ... through the law of privacy'. ${ }^{31}$

The court agreed that: '[g]iven the presumption of public justice the statutory intervention under Article 22 is necessary to protect the Article 6 and Article 8 rights of children who are brought before the courts', as '[o]therwise their identity will become public'. ${ }^{32}$ It was asserted that the risk post-charge that a minor's identity would be made public derives from the principle of open justice, with media and public scrutiny of proceedings in court a present feature of open justice. The court observed that this 'is not the case with children who are in the "pre-charge" situation'. ${ }^{33}$ Further, it was deemed that the risk of identification is significantly less, and, therefore, the applicant in this case was 'not in a relevantly analogous situation to children who actually appear before a court'.34

On 26 March 2020, the High Court held that the Department of Justice's failure to provide the applicant with pre-charge anonymity was not discriminatory and did not amount to a breach Article 14 of the ECHR. ${ }^{35}$ In his judgment, Colton J concluded that he was satisfied that there existed a rationale behind the failure to commence section $44^{36}$ and that any differential treatment had 'a legitimate aim'. ${ }^{37}$

26 Ibid paragraph 49.

27 Ibid paragraph 50.

28 Ibid paragraph 59.

29 Ibid paragraph 60.

30 Ibid.

31 Ibid paragraph 61.

32 Ibid paragraph 70.

33 Ibid. Emphasis in original.

34 Ibid paragraphs 70, 71.

35 Ibid paragraph 71.

36 Ibid paragraphs 71, 72.

37 Ibid. 


\section{The need for principled reform}

Colton $\mathrm{J}$ has acknowledged that this case raises an important social issue. As argued elsewhere, the current media regulatory frameworks in the UK do not offer sufficient precharge protection for minors. ${ }^{38}$ The international children's rights framework provides important requirements to ensure the protection of children from stigmatisation and further harm when they come into contact with the criminal justice system. For example, Article 16 of the UN Convention on the Rights of the Child 1989 states that among the guarantees for '[e]very child alleged as or accused of having infringed the penal law' is that 'his or her privacy [be] fully respected at all stages of the proceedings', and the UN Standard Minimum Rules for the Administration of Justice (the Beijing Rules) require a child's 'right to privacy' be 'respected at all stages' of the criminal justice process, 'in order to avoid harm being caused ... by undue publicity or by the process of labelling', and 'no information that may lead to the identification of a juvenile offender shall be published'. 39

However, in the JKL judgment the court's specific focus on risk of identification failed to consider identification and ramifications of identification for minors specifically. While the judgment appears to engage with rights under the ECHR, it does not appear to engage with these in a practical sense. Further to this, any discussion of the digital age is omitted. In the context of social media, there are central issues relating to permanency and thirdparty sharing which have not been explored. The case offered a key opportunity to address considerations of practical issues, but it failed to do so adequately. Rather, the court placed the onus on the common law to offer protection for minors through the law of privacy. In doing so, the court has failed to address the suitability of these available protections after the event of identification and after identity is known in the public domain. As this case has demonstrated, such existing protections are clearly not adequate.

\section{Conclusion}

This case is significant as it shines a much-needed light on the issues experienced by minors identified pre-charge and the lack of protections that exist. However, this case also represents a missed opportunity to address such significant issues. As the opening quotation demonstrates, it is possible to significantly negatively influence the 'foundation of justice' before it commences. ${ }^{40}$ Thus, in this area of pre-charge identification, there is a direct and urgent need for legislative intervention and significant reform. The impact of the ever-changing environment of the digital age, with increased levels of third-party commentary and the permanency of the imagery shared on social media platforms, present significant challenges which need to be addressed by legislation, policy and regulatory frameworks in order to fully protect the rights of individuals pre-charge.

38 F Gordon 'Media regulation: strategies to mitigate the violence perpetrated against children who are publicly "named and shamed"' in W O'Brien and C Foussard (eds), Violence against Children in the Criminal Justice System: Global Perspectives on Prevention (Routledge 2020).

39 UN General Assembly 1985, rules 8.1, 8.2.

$40 \mathrm{R} v$ Parke, cited in Burgess (n 1). 